\title{
Minor Elements in Shallow-Water Deposits from Nanao Bay, Japan*
}

\author{
Yoshikazu Yамамото**
}

\begin{abstract}
The minor elements $\mathrm{Ni}, \mathrm{Co}, \mathrm{Cu}, \mathrm{Zn}, \mathrm{Pb}, \mathrm{Cd}, \mathrm{Cr}, \mathrm{V}, \mathrm{Mo}, \mathrm{Zr}$ and $\mathrm{Ga}$ were studied in 21 samples of shallow-water deposits from West, South and North Bays of Nanao. Ni (av. $14 \pm 5 \mathrm{ppm}$ ), Co (av. 6 $\pm 2 \mathrm{ppm}$ ), $\mathrm{Zn}$ (av. $51 \pm 7 \mathrm{ppm}$ ), V (av. $39 \pm 6 \mathrm{ppm}$ ) and Mo (av. $0.5 \pm 0.3$ $\mathrm{ppm}$ ) were not so much concentrated in these deposits as in pelagic deposits, but only Ga (av. $12 \pm 3 \mathrm{ppm}$ ) shows concentration similar to that in pelagic sediment. It is characteristic of these deposits that $\mathrm{Pb}$ (av. $55 \pm 6 \mathrm{ppm}$ ) and $\mathrm{Zr}$ (av. $101 \pm 46 \mathrm{ppm}$ ) are notably abundant in them, compared with those of shallow-water deposits from all the coasts of Honshu, Japan, Korean coast and Gulf of Paria. The constancy of $\mathrm{Co} / \mathrm{Ni}$ ratios was found in these deposits and red clays despite large difference in abundance of these elements in them. There are positive correlations between the contents of $\mathrm{Ni}, \mathrm{Zn}$ and $\mathrm{Ga}$ and content of $\mathrm{Al}$, and also between the contents of $\mathrm{V}$ and $\mathrm{S}$.
\end{abstract}

\section{Introduction}

In the previous paper (YAMAMOTO, 1968) the analyses of major chemical constituents on the 21 samples of shallow-water deposits from West, South and North Bays of Nanao were reported with geological outline. In the present investigation the minor elements, $\mathrm{Ni}, \mathrm{Co}, \mathrm{Cu}, \mathrm{Zn}, \mathrm{Pb}$, $\mathrm{Cd}, \mathrm{Cr}, \mathrm{V}, \mathrm{Mo}, \mathrm{Zr}$ and $\mathrm{Ga}$ in the same samples were determined.

The contents and the regional characteristics of distribution of elements in the deposits of each bay were clarified together with relations between the contents of major and minor elements. The comparison of abundance values of minor elements in these deposits with the average values of other shallow- and deep-sea sediments or of rocks is also discussed.

\section{Samples and methods of analyses}

Samples air-dried were pulverized, dried at $105-110^{\circ} \mathrm{C}$ to a constant weight, and subjected to the analysis. The samples were classified into 3 groups [West Bay (Sample No. 1-5P), South Bay (Sample No. 6-101 ), and North Bay (Sample No. 11-19)] according to the geographical distribution.

\footnotetext{
* Received May 4, 1968

** Faculty of Technology, Kanazawa University
}

Determinations of $\mathrm{Ni}, \mathrm{Co}, \mathrm{Cu}, \mathrm{Zn}, \mathrm{Pb}, \mathrm{Cd}, \mathrm{Cr}$, $\mathrm{V}$ and Mo were done by the colorimetric method of SANDELL (1950) with some minor modifications (IsHIBASHI et al., 1958, 1959, 1960, 1962, 1964; UedA, 1957; Yамамото, 1960). Zirconium was determined by the Alizaline $\mathrm{S}$ method of DEGENHARDT (1956), Gallium was analyzed fluorometrically by the method of NISHIKAWA (1958).

\section{Results and discussion}

The results of the analyses of minor elements in Nanao Bay deposits are given in Table 1. In Table 2, the average values for West, South and North Bays are shown. The determination was carried out with $10 \%$ of error. The ratios of each minor element concentration in the deposits and those in igneous or pelagic sediments are summarized in Figs. 1 and 2.

The conclusions drawn from the distributions are found in the paragraphs on differents below.

Nickel and Cobalt-The nickel and cobalt contents of these deposits range from 4 to $24 \mathrm{ppm}$ and 2 to $12 \mathrm{ppm}$ with the average of $14 \pm 5$ and $6 \pm 2 \mathrm{ppm}$ respectively.

The deposits of Nanao Bay show values little less than those of the shallow-water deposits of all the coasts of Honshu, Japan and of Korean coast in the average contents of these elements. 

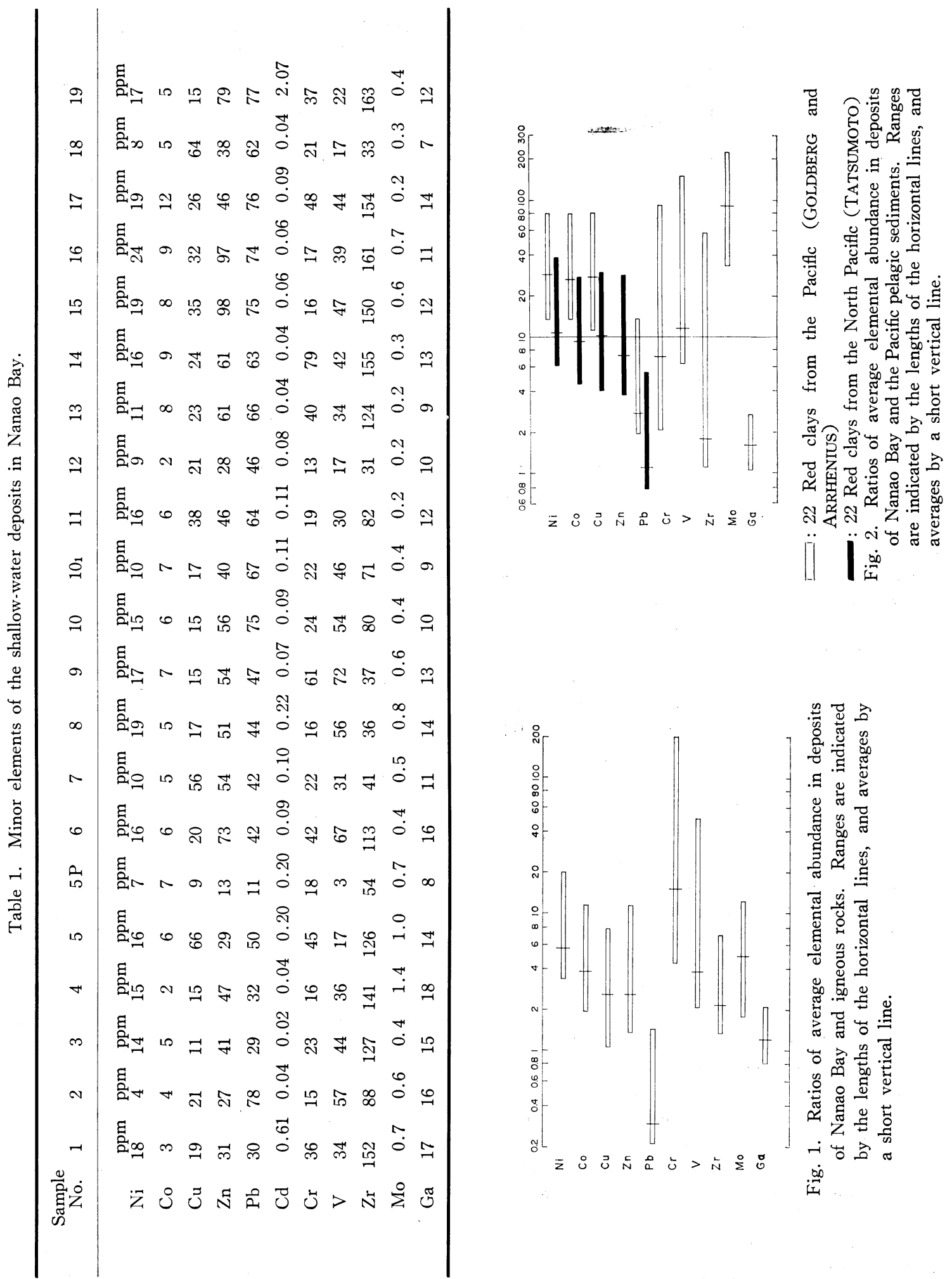
Table 2. Average minor elements in the shallow-water deposits of three groups from Nanao Bay.

\begin{tabular}{lcccc}
\hline & $\begin{array}{l}\text { Deposits of } \\
\text { West Bay } \\
\text { (6 specimens) }\end{array}$ & $\begin{array}{l}\text { Deposits of } \\
\text { South Bay } \\
(6 \text { specimens })\end{array}$ & $\begin{array}{l}\text { Deposits of } \\
\text { North Bay } \\
(9 \text { specimens) }\end{array}$ & $\begin{array}{l}\text { All deposits } \\
\text { of Nanao Bay } \\
(21 \text { specimens })\end{array}$ \\
\hline $\mathrm{Ni}$ & $12 \pm 5 \mathrm{ppm}$ & $15 \pm 3 \mathrm{ppm}$ & $15 \pm 5 \mathrm{ppm}$ & $14 \pm 5 \mathrm{ppm}$ \\
$\mathrm{Co}$ & $5 \pm 2$ & $6 \pm 1$ & $7 \pm 3$ & $6 \pm 2$ \\
$\mathrm{Cu}$ & $24 \pm 19$ & $23 \pm 15$ & $31 \pm 14$ & $27 \pm 16$ \\
$\mathrm{Zn}$ & $31 \pm 11$ & $55 \pm 10$ & $62 \pm 24$ & $51 \pm 7$ \\
$\mathrm{~Pb}$ & $38 \pm 21$ & $53 \pm 13$ & $67 \pm 7$ & $55 \pm 6$ \\
$\mathrm{Cd}$ & $0.22+0.21$ & $0.11 \pm 0.05$ & $0.29 \pm 0.63$ & $0.22 \pm 0.43$ \\
$\mathrm{Cr}$ & $25 \pm 12$ & $31 \pm 16$ & $32 \pm 20$ & $30 \pm 5$ \\
$\mathrm{~V}$ & $32 \pm 18$ & $54 \pm 12$ & $32 \pm 11$ & $39 \pm 6$ \\
$\mathrm{Zr}$ & $115 \pm 34$ & $63 \pm 28$ & $117 \pm 51$ & $101 \pm 46$ \\
$\mathrm{Mo}$ & $0.8 \pm 0.5$ & $0.5 \pm 0.5$ & $0.3 \pm 0.4$ & $0.5 \pm 0.3$ \\
$\mathrm{Ga}$ & $15 \pm 2$ & $12 \pm 2$ & $11 \pm 2$ & $12 \pm 3$ \\
\hline
\end{tabular}

Comparing with the average figures of other workers (TATSUMOTO, 1956; GOLDBERG and ARRHENIUS, 1958; SANDELl et al., 1943), the average contents of nickel and cobalt in these deposits are depleted than in red clays or igneous rocks.

The average ratio of $\mathrm{Co}$ to $\mathrm{Ni}$ in Nanao Bay sediments is 0.43 and is in good agreement with that of sediments of the Pacific red clay $(0.50$, GOLDBERG et al., 1958;0.37, TATSUMOTO, 1956) or that of hydrolyzate (0.4, RANKAMA, 1950), in spite of a great differences exist on the contents of $\mathrm{Ni}$ and $\mathrm{Co}$ among them.

As shown in Fig. 3, a positive correlation between the contents of nickel and aluminum was found. A similar relation can be found between the contents of cobalt and aluminum.

Copper and Zinc-The average copper content in these deposits is $27 \pm 16 \mathrm{ppm}$ ranging from 9 to $66 \mathrm{ppm}$, and the zinc ranges from 13 to $98 \mathrm{ppm}$ with the average of $51 \pm 7 \mathrm{ppm}$.

The average values of copper and zinc in the deposits in Nanao Bay, are less than those in pelagic sediments or in igneous rocks.

The average $\mathrm{Cu} / \mathrm{Zn}$ ratio for these deposits, 0.53 , agrees those of 0.45 and 0.53 for igneous rocks (SANDELL and GOLDICH, 1943; LUNDEGARDH, 1946, 1947), but differ from that of 0.73 for red clay (TATSUMOTO, 1956).

The relation between the contents of zinc and aluminum is shown in Fig. 4.



Fig. 3. Relationship between the contents of nickel and aluminum in deposits of Nanao Bay.

There is a positive correlation between the contents of zinc and nickel with 0.95 of correlation factor, as is shown in Fig. 5, as well as a similar relation can be surmised between those of zinc and cobalt.

Lead-The lead contents of these deposits range from 11 to $78 \mathrm{ppm}$ with the average of $55 \pm 6$ ppm. The average lead content of these deposits 


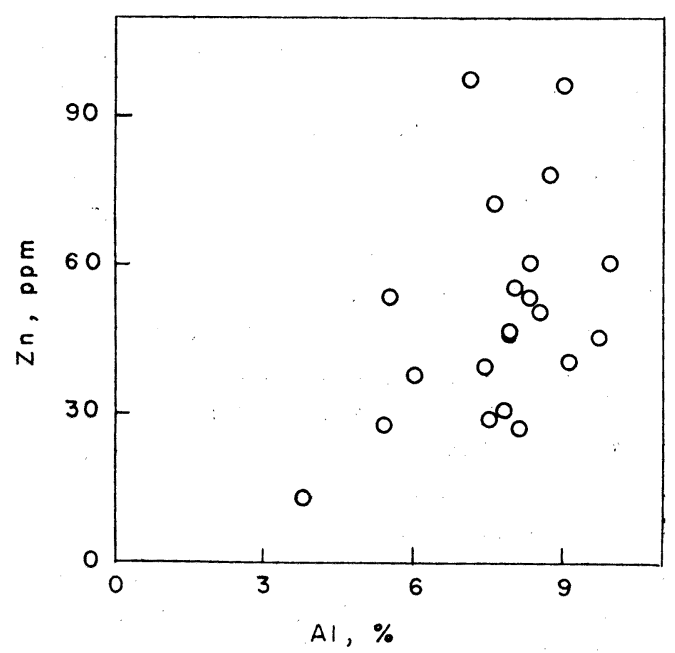

Fig. 4. Relationship between the contents of zinc and aluminum in deposits of Nanao Bay.

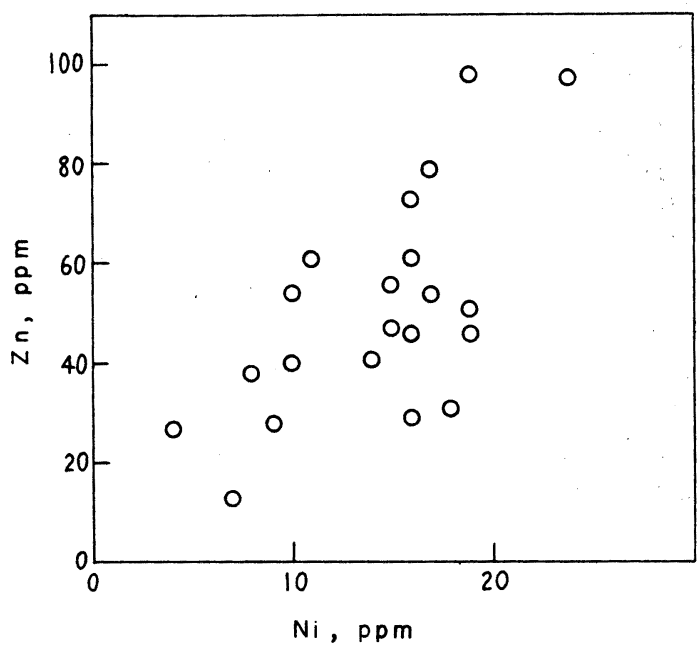

Fig. 5. Relationship between the contents of zinc and nickel in deposits of Nanao Bay.

is remarkably higher than those of the shallowwater deposits from all the coasts of Honshu, Japan, Korean coast and Gulf of Paria, or that of igneous rocks, and is in the same order of magnitude with values on the pelagic sediments in the North Pacific given by TATSUMOTO (1957).

No clear relationship between the contents of lead and major elements is found, but there is a tendency that sediments with high concentration of lead are generally rich in the contents of nickel, cobalt and zinc.
Cadmium-The cadmium content ranges from 0.04 to $2.07 \mathrm{ppm}$ with the average of $0.22 \pm 0.43$ ppm. The average content of cadmium in Nanao Bay sediments is in the same order of magnitude with those of igneous rocks.

Chromium and Vanadium-The average content of chromium in the sediments of Nanao Bay is $30 \pm 5 \mathrm{ppm}$, and the content is particularly lower than those in red clays (93 ppm) and igneous rocks $(200 \mathrm{ppm})$.

There can not be found any correlation between chromium and aluminum contents of the deposits; despite there are similarity of their chemical properties, ionic size and ionic charge.

EMERY (1960) stated that the abundance of chromium in several cores are closely paralleled with calcium and strontium, but in Nanao Bay deposits, no clear relationship of chromium to calcium can be found.

In these deposits the vanadium contents are remarkably low in Sample $5 \mathrm{P}(3 \mathrm{ppm})$, and relatively high in Samples 9 and 14 (72 and 42 $\mathrm{ppm})$. The average vanadium content of the deposits $(39 \pm 6 \mathrm{ppm})$, is particularly lower than those in the red clays ( $450 \mathrm{ppm}$ from the Pacific or in igneous rocks (150 ppm).

A positive relation of vanadium to sulfur is found in the deposits, as shown in Fig. 6. This is attributable that in an anoxic condition, vanadium precipitate in a sediment as sulphide $\mathrm{V}_{2} \mathrm{~S}_{5}$ as pointed by RANKAMA (1950).

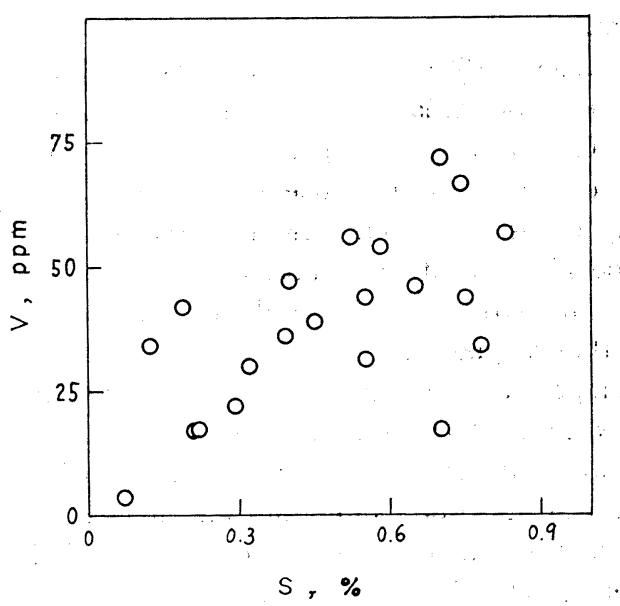

Fig. 6. Relationship between the contents of vanadium and sulfur in deposits of Nanao Bay. 
The average $\mathrm{Cr} / \mathrm{V}$ ratio in the deposits, 0.77 , agrees with those of $0.76,0.79$ and 0.74 for shallow-water deposits from all the coasts of Honshu, Japan, Korean coast and the Gulf of Paria (HIRsT, 1962). The average $\mathrm{Cr} / \mathrm{Fe}$ ratio, $0.09 \times 10^{-2}$ in the deposit of Nanao Bay, is in the same order of magnitude with those of 0.10 $\times 10^{-2}, \quad 0.10 \times 10^{-2}$, and $0.14 \times 10^{-2}$ in the deposits from all the coasts of Honshu, Japan and Korean coast, and the sands from the Gulf of Paria and the red clays of the Pacific, respectively.

Zirconium-Zirconium content of these deposits show an appreciable extent of variation ranging from 31 to $163 \mathrm{ppm}$.

The average zirconium content of the deposits, $101 \pm 46 \mathrm{ppm}$, is $2-4$ times higher than $27-48$ ppm of the deposits of all the coasts of Honshu, Japan and $44-65 \mathrm{ppm}$ of Korean coast, but is about half as much as $180 \mathrm{ppm}$ of deep-sea sediments or $220 \mathrm{ppm}$ of igneous rocks.

The highest zirconium content among these deposits is $163 \mathrm{ppm}$ of Sample 19, which is characterized by higher concentrations of other minor elements such as cadmium, zinc and lead. It is found that zirconium contents are high in the deposits rich in aluminum and phosphorus. On the contrary, there is little correlation between the contents of zirconium and titanium despite notable similarity of their general characters.

Molybdenum-The average molybdenum content is $0.5 \pm 0.3 \mathrm{ppm}$ ranging from 0.2 to 1.4 ppm.

HIRST (1962) found that the molybdenum contents of Paria sediments range from 0.01 to $1.1 \mathrm{ppm}$ which is in good agreement with the present result of molybdenum content in Nanao Bay deposits. While, OKABE (1961) reported a little higher content of molybdenum of 1.0 to 4.7 ppm for coastal marine sediment in Japan. As to the molybdenum contents of lithosphere, the average value is about $1 \mathrm{ppm}$ (KURODA and SANDELL, 1954; VINOGRADOV, 1958).

No relation between the contents of molybdenum and iron, aluminum and manganese can be seen in these deposits, despite the similarity their geochemical behaviors.

Gallium-Gallium is known as one of environmental discriminators with boron, lithium and vanadium. From such point of view, the abundance and behavior of gallium in marine sediments may be worth paing attention.

The gallium contents of these deposits range from 7 to $18 \mathrm{ppm}$ with the average of $12 \pm 3 \mathrm{ppm}$ which is somewhat lower than the averages, 19 , 15 and $22 \mathrm{ppm}$ for deep-sea sediments, igneous rocks and muds from Gulf of Paria (HIRsT, 1962), respectively. The similar concentration of gallium was reported by present authors (1966) and POTTER et al. (1963) for the shallow-water, marine or fresh-water sediments.

It is to be noted that gallium, unlike the other minor elements, such as nickel, cobalt, copper, zinc, vanadium and molybdenum, is characterized as the element of no remarkable accumulation in deep-sea sediments.

In Fig. 7 a positive relation of gallium to aluminum in these deposits is shown. Probably this relation is caused by the similarities of their chemical properties and ionic radii of gallium and aluminum ions, 0.62 and $0.57 \AA$, respectively, as pointed out by RANKAMA (1950) and HIRST (1962).

The average $\mathrm{Ga} / \mathrm{Al}$ ratio for the deposits, $0.16 \pm 10^{-3}$, is a little less than the ratios of $0.12 \times 10^{-3}$ and $0.23 \times 10^{-3}$ for deposits from various small islands and Paria sediments, respectively. The average $\mathrm{Ga} / \mathrm{Al}$ ratios of groups $\mathrm{W}$, $\mathrm{S}$ and $\mathrm{N}$ are $0.20 \times 10^{-3}, 0.16 \times 10^{-3}$ and $0.14 \times$ $10^{-3}$ respectively.

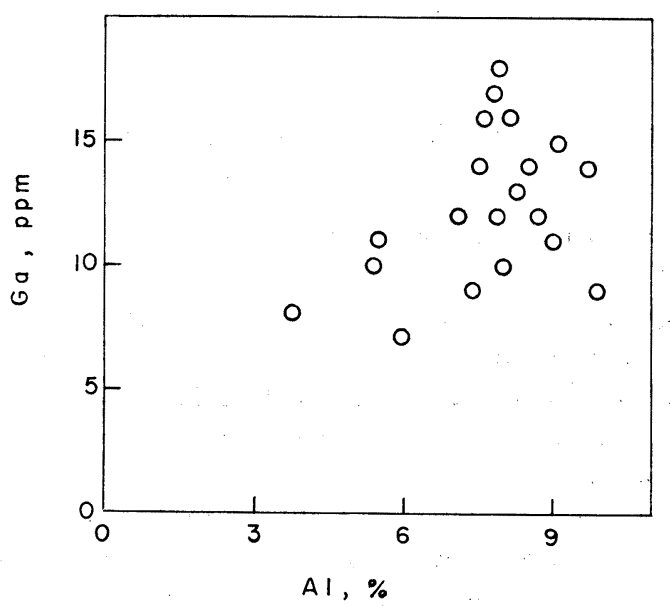

Fig. 7. Relationship between the contents of gallium and aluminum in deposits of Nanao Bay. 




Fig. 8. Relationship between the contents of gallium and cobalt in deposits of Nanao Bay.

\section{Acknowledgements}

The author wishes to express his sincere thanks to Dr. Masayoshi IsHibASHI, Ex-President of the Kanazawa University, for his kind encourgement. Thanks are also due to Professors Shunzo UEDA and Yoshio KASENO of the Kanazawa University for their valuable advice throughout this study.

\section{References}

DEgENHARDT, H. (1956): Determination of small amounts of zirconium in rocks, minerals, and waters. Z. Anal. Chem., 153, 327-335.

EMERY, K. O. (1960): The Sea off Southern California. John Wiley and Sons, Inc., New York, $234 \mathrm{pp}$.

GoldBerG, E. D. and G. O. Arrhenius (1958): Chemistry of Pacific pelagic sediments. Geochim. Cosmochim. Acta, 13, 153-212.

HIRST, D. M. (1962): The geochemistry of modern sediments from the Gulf of Paria-II. The location and distribution of trace elements. Geochim. Cosmochim. Acta, 26, 1147-1187.

ISHIBASHI, M., S. UEDA, Y. YAMAMOTO and F. MORII (1958): Studies on the utilization of the shallow-water deposits (Continued). On the copper content of the shallow-water deposits at the sea-coasts of the Kii Peninsura and the other districts. Jour. Oceanogr. Soc. Japan, 14, 153-166.

IsHIBASHI, M., S. UEDA and Y. YAMAMOTO (1959): Studies on the utilization of the shallow-water deposits. Rec. Oceanogr. Wks. Japan, (S. N.) 3, 123-133.
IsHiBASHI, M., S. UEDA and Y. YAMAMOTO (1960): Studies on the utilization of shallow-water deposits (Continued). On the lead content of the shallow-water deposits. Rec. Oceanogr. Wks. Japan (S. N.) 4, 111-122.

IsHibashi, M., S. UedA and Y. YAMAMoto (1962): Studies on the utilization of shallow-water deposits (Continued). On the cadmium content of shallow-water deposits. Rec. Oceanogr, Wks. Japan, 6(2), 169-176.

IsHIBASHI, M., S. UEDA and Y. YAMAMOTO (1964): Studies on the shallow-water deposits (Continued). On the cobalt and nickel contents of the shallowwater deposits. Rec. Oceanogr. Wks. Japan, 7(2), 37-42.

IshiBASHI, M., S. UEDA and Y. YAMAMOTO (1966): On the gallium content of the shallow-water deposits. Jour. Oceanogr. Soc. Japan, 22 (5), 197-200.

Kuroda, P. K. and E. B. SANDell (1954): Geochemistry of molybdenum. Geochim. Cosmochim. Acta, 6, 35-63.

LUNDEGARDH, PER H. (1946): Rock composition and development in Central Roslagen, Sweden. Arkiv Kemi, Mineral. Geol. 23A, No. 9.

LUNDEGARDH, PER H. (1947): Some aspects to the determination and distribution of zinc. Ann. Roy. Agr. Coll. Sweden 15.

NishiKAWA, Y. (1958): Studies on the fluorometric analysis. VII. Determination of gallium in silicate rocks with 8-Hydroxyquinaldine. Nippon Kagaku Zasshi, 79, 236-238. (In Japanese)

OKABE, S. (1961): Geochemistry of molybdenum in natural waters. Bull. Fukuoka Gakugei Univ., 11, 57-92. (In Japanese)

PotTer, P. E., N. F. SHIMP and J. WitTers (1963): Trace elements in marine and fresh-water argrillaceous sediments. Geochim. Cosmochim. Acta, 27, 669-694.

RANKAMA, K. and T. G. SAhama (1950): "Geochemistry", Univ. Chicago Press, pp. 601, 685, 720 ,

SANDELL, E. B. (1950): "Colorimetric Determination of Traces of Metals". 3rd ed., Interscience Publishers, New York, pp. 360, 398, 429, 460, 572, 659, 676, 934, 955.

SANDELl, E. B. and S. S. Goldich (1943): The rarer metallic constituents of some American igneous rocks. I. J. Geol. 51, p. 99; II. ibid., p. 167.

TAtsumoto, M. (1956): Chemical studies on the deep-sea deposits. XXI. The contents of cobalt and nickel in sea sediments. (1). Nippon Kagaku Zasshi, 77, 1637-1642. (In Japanese) 
Tatsumoto, M. (1957): Chemical studies on the deep-sea deposits. XXII-XXIII. XXII. The contents of cobalt and nickel in sea sediments. (2). Nippon Kagaku Zasshi, 78, 38-42; XXIII. The Contents of tin and lead in sea sediments. ibid., 78, 42-48. (In Japanese)

TAтsumoto, M. (1957): Chemical investigations of deep-sea deposits. XXIV-XXV. XXIV. Nippon Kagaku Zasshi, 78, 405-409; XXV. The Contents of copper and zinc in sea sediments. (2)., ibid., 78, 409-415. (In Japanese)

UEDA, S. (1957): Chemical studies on the oceanLXIII. Chemical studies of the shallow-water deposits-21. Vanadium and chromium contents of the shallow-water deposits (1). Jour. Oceanogr.
Soc. Japan, 13, 93-97. (In Japanese)

VINOGRADOV, A. P. (1958): Regularity of distribution of chemical elements in the earth's crust. Geochemistry, No. 1, 24-25.

Vinogradov, A. P., E. E. VAINShTEIN and L. I. PAVlenKo (1958): Tungsten and molybdenum in igneous rocks. Geochemistry, No. 5, 497-509.

YAmamoto, Y. (1960): Chemical studies on the ocean-LXXXVI. Molybdenum content of the shallow-water deposits (1). Jour. Oceanogr. Soc. Japan, 16(4), 163-166. (In Japanese)

YAMAMOTO, Y. (1968): The chamical composition of shallow-water deposits of Nanao Bay, Japan. Jour. Oceanogr. Soc. Japan, 24(3), 94-102.

\section{七尾湾浅海底土の微量元素}

山本善 一

要旨 七尾湾西湾, 南湾, および北湾から採取した 21 個 の浅海底土試料中の微量元素, ニッケル, コバルト, 銅, 亜鈶, 鈶, カドミゥム, クロム, バナジウム, モリブデ ン, ジルコニウム, ガリウムを定量した. これらの微量 元素のらち, ニッケル (平均值 $14 \pm 5 \mathrm{ppm}$ ), コバルト (平均値 $6 \pm 2 \mathrm{ppm}$ ), 覀鈶（平均値 $51 \pm 7 \mathrm{ppm),} \mathrm{バナジゥ}$ 厶 (平均值 $39 \pm 6 \mathrm{ppm}$ ), モリブデン（平均值 $0.5 \pm 0.3$ ppm）は遠洋深海堆積物ほど, これらの浅海堆積物には

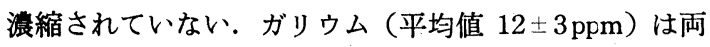
堆積物中にほほ同じ程度の存在量を示す. 鈶（平均值

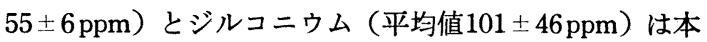
州, 朝鮮沿岸および Paria 湾からの浅海堆積物に比較す ると，七尾湾堆積物にかなり多い点が注目される.

また七尾湾浅海堆積物と深海堆積物の赤粘土を比べる と両者のニッケルとコバルト含量に大きな差異があるに もかかわらず, $\mathrm{Co} / \mathrm{Ni}$ の比がほほ一定であることがわ かった.

ニッケル，亜鈶，ガリウム含量とアルミニウ含量との 間には正の相関々係があり, またバナジウム含量と硫黄 含量との間にも同様の関係が認められる. 